\title{
KLASTERISASI SELEKSI MAHASISWA CALON PENERIMA BEASISWA YAYASAN MENGGUNAKAN $K$-MEANS CLUSTERING
}

\author{
Sabrina Aulia Rahmah ${ }^{1}$, Jovi Antares ${ }^{2}$ \\ 1,2,Universitas Dharmawangsa \\ Jl. K.L.Yos Sudarso No. 224, Medan, 20115 \\ e-mail : sabrinaaulia@dharmawangsa.ac.id
}

\begin{abstract}
ABSTRAK
Perekomendasian untuk penerima beasiswa Yayasan dikelompokkan menjadi 3 clsuter yaitu, diterima, dipertimbangkan dan ditolak sebagai penerima beasiswa yayasan. Algoritma K-Means Clustering merupakan salah satu teknik unsupervised learning yang digunakan untuk merekomendasi penerima beasiswa yayasan. Adapun tujuan dari penelitian ini adalah untuk merekomendasikan calon penerima beasiswa yayasan dengan menggunakan algoritma K-Means Clustering, rekomendasi meghasilkan penempatan data pendaftar beasiswa ke masing-masing kelompok cluster yang dihasilkan. Data pendaftar yang digunakan sebanyak 80 pendaftar. Melalui penyeleksian atribut k-means melakukan perhitungan untuk menempatkan setiap data ke cluster yang sudah ditentukan. Hasil dari perhitungan yang telah diolah sebanyak 16\% diterima, $61 \%$ dipertimbangkan dan $23 \%$ ditolak.
\end{abstract}

Kata kunci : Beasiswa, Clustering, K-Means Clustering, Hypertext Preprocessor (PHP)

\begin{abstract}
Recommendations for Foundation scholarship recipients are grouped into 3 clusters, namely, acceptance, consideration and rejection as foundation scholarship recipients. The K-Means Clustering algorithm is one of the unsupervised learning techniques used to recommend foundation scholarship recipients. The purpose of this study is to recommend prospective foundation scholarship recipients using the K-Means Clustering algorithm, the recommendations result in the placement of scholarship applicant data into each of the resulting cluster groups. Registrant data used as many as 80 registrants. Through selecting the k-means attribute, it performs calculations to place each data into a predetermined cluster. The results of the calculations that have been processed are $16.3 \%$ accepted, $61.3 \%$ considered and $22.5 \%$ rejected.
\end{abstract}

Keywords : Scholarship, Clustering, K-Means Clustering, Hypertext Preprocessor (PHP)

\section{PENDAHULUAN}

Banyak jenis beasiswa yang ditawarkan untuk seseorang melanjutkan pendidikan ke tingkat perguruan tinggi diantaranya adalah beasiswa Yayasan. Beasiswa Yayasan merupakan beasiswa yang diberikan oleh Yayasan bagi calon mahasiswa baru untuk masuk perguruan tinggi swasta. Salah satunya adalah Yayasan Pendidikan Dharmawangsa, yayasan memberikan beasiswa berupa gratis uang kuliah selama 4 tahun dengan kata lain selama awal mula kuliah hingga akhir kuliah. Beasiswa diberikan kepada mahasiswa yang kurang mampu dari segi finansial ekonomi tetapi memiliki keinginan untuk melanjutkan pendidikan ke jenjang perguruan tinggi. Beasiswa ini biasanya disalurkan langsung oleh perguruan tinggi yang bersangkutan. Beasiswa sendiri diberikan kepada siswa sekolah tingkat SMA/ SMK yang baru lulus atau paling lama 2 tahun setelah lulus SMA/SMK.

Untuk seleksi pendaftaran beasiswa yayasan memiliki persyaratan-persyaratan yang harus dipenuhi calon mahasiswa penerima sebelum 
IN F ORM A I I A

Jurnal Informatika, Manajemen dan Komputer, Vol. 13, No. 2, Desember 2021

eISSN : 2580-3042

pISSN : 1979-0694

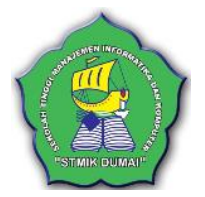

menerimanya. Adapun syarat yang harus dipenuhi diantaranya adalah Nilai Ujian Akhir Sekolah (UAS), Nilai Rapor, Status Rumah, Kondisi Rumah, Penghasilan Orang tua. Dalam penyeleksian penerima beasiswa yayasan digunakan algoritma $K$-Means Clustering.

Data mining merupakan serangkaian proses untuk menggali nilai tambah berupa informasi yang selama ini tidak diketahui secara manual dari suatu basis data. Data mining mulai ada sejak 1990 -an sebagai cara yang benar dan tepat untuk mengambil pola dan informasi yang digunakan untuk menemukan hubungan antara data untuk melakukan pengelompokkan ke dalam satu atau lebih Cluster sehingga objek - objek yang berada dalam satu Cluster akan mempunyai kesamaan yang tinggi antara satu dengan lainnya (Putri et al., 2021).

Clustering bisa diartikan sebagai identifikasi kelas objek yang memiliki kemiripan dengan data yang lain. Dengan menggunakan teknik Clustering dapat mengidentifikasi kepadatan dan jarak daerah dalam objek ruang dan dapat menemukan secara keseluuhan pola distribusi dan kolerasi antara atribut (Ginting \& Riandari, 2020).

Algoritma K-Means merupakan algoritma pada unsupervised learning pada proses Clustering yang mengelompokan data berdasarkan kemiripan / kesamaan. Data dengan karakter sama akan dikelompokkan pada satu Cluster sedangkan data dengan karakter berbeda akan dikelompokkan pada Cluster yang lain (Salam et al., 2020).

Algoritma ini digunakan untuk mengelompokkan calon penerima beasiswa dalam 3 kategori yaitu diterima, dipertimbangkan dang ditolak. Dengan menggunakan Algoritma $K$-Means Clustering dapat membantu klasterisasi pengusulan calon mahasiswa penerima beasiswa kedalam kategori yang layak dan tidak layak untuk menerima beasiswa sesuai dengan kriteriakriteria yang sudah ditentukan. Penggunaan Algoritma K-means dilakukan karena sudah banyak penelitian terhadap pengelompokkan suatu hal yang menggunakan Clustering.

Pada penelitian sebelumnya Algoritma $K$ means dilakukan dalam hal menentukan beasiswa yayasan dengan menghasilkan empat golongan berdasarkan jumlah dari kriteria, hasil pengelompokan memperlihatkan jumlah dan keputusan yayasan terhadap pemberian beasiswa terhadap mahasiswanya. (Sudarsono \& Lestari, 2021). Pada penelitian yang lain Algoritma Kmeans dapat membantu untuk mengklasifikasi

siswa-siswi yang sangat layak dalam mendapatkan bantuan berupa beasiswa, dari 128 data set yang di gunakan menghasilkan perhitungan yang diperoleh sebesar $\mathrm{C} 1: 73$ item, C2: 30 item dann C3: 25 Item (Manihuruk et al., 2020). Algoritma K-Means Clustering juga digunakan dalam mengelompokkan provinsi lampung yang terkena kasus covid-19 dengan membagi kedalam 4 Cluster yaitu zona merah, zona orange, zona kuning dan zona hijau (Teknologi et al., 2021).

Algoritma K-means Clustering adalah salah satu cara untuk mengkluster sebuah kumpulan data dan membagi data tersebut untuk membentuk sebuah Cluster yang baru (Rahayu et al., 2019). K-Means Clustering merupakan salah satu metode data Clustering non hirarki yang berusaha mempartisi data yang ada kedalam bentuk satu atau lebih Cluster sehingga data yang memiliki karakteristik yang sama dikelompokkan dalam satu Cluster (Rahmah, 2020).

Dalam penelitian ini pengujiam data menggunakan aplikasi PHP yang berbasis web yang dapat diakses menggunakan browser, yang mana sampel yang digunakan adalah data-data dari calon mahasiswa penerima beasiswa yayasan yang telah mendaftar sebelumnya. PHP adalah akronim dari Hypertext Preprocessor, yaitu suatu bahasa pemrograman berbasiskan kode-kode (script) yang digunakan untuk mengolah suatu data dan mengirimkannya kembali ke web browser menjadi kode HTML (Hasan \& Muhammad, 2020).

\section{METODOLOGI PENELITIAN}

Kerangka penelitian adalah sebuah alur yang dibuat untuk memudahkan penelitu dalam menyelesaikan tahapan masalah.

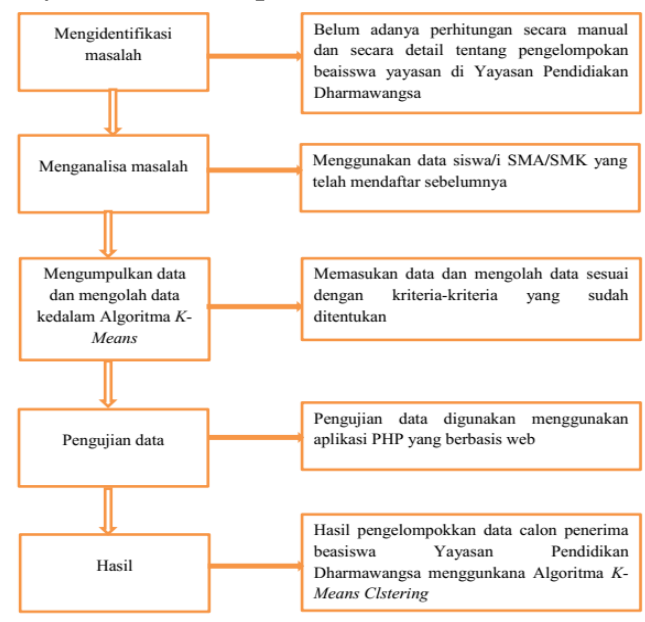

Gambar 1. Kerangka Penelitian 
IN F ORM T IK A

Jurnal Informatika, Manajemen dan Komputer, Vol. 13, No. 2, Desember 2021

eISSN : 2580-3042

pISSN : 1979-0694

1. Mengidentifikasi masalah

Identifikasi masalah dilakukan sebelum adanya perhitungan data secara manual dan secara detail tentang pengelompokkan beasiswa yayasan di Yayasana Pendidikan Dharmawangsa.

2. Menganalisa masalah

Setelah masalah diidentifikasi tahapan selanjutnya adalah menganalisa masalah dengan menggunakan data siswa/i SMA/SMK yang telah mendaftar untuk calaon mahasiswa penerima beasiswa yayasan.

3. Mengumpulkan data dan Mengolah data kedalam Algoritma K-Means Clustering

Data yang telah dikumpulkan akan langsung diolah dengan menggunakan rumus Algoritma K-Means yang sudah ada, dan sesuai dengan kriteria yang sudah ditentukan.

4. Pengujian data

Data diuji menggunakan aplikasi PHP yang berbasis web untuk memudahkannya dalam membaca hasil pengelompokkan.

5. Hasil

Hasil yang didapat berupa grafik visualisasi persantase hasil data yang telah diolah.

\section{HASIL DAN PEMBAHASAN}

Dalam pemanfaatan algoritma $K$-Means Clustering dalam mengelompokkan calon penerima beasiswa dibutuhkan data yang terkait. Sumber data penelitian didapat dari data yang dikumpulkan sebelumnya. Data yang digunakan dalam penelitian ini adalah Nilai Ujian Akhir Sekolah (UAS), Nilai Rapor, Status Rumah, Kondisi Rumah dan Penghasilan Orang Tua yang terdiri dari 30 calon mahasiswa, data yang diperolah diolah dengan melakukan pembagian terhadap 3 Cluster yaitu Diterima, Dipertimbangkan dan Ditolak.

Algoritma K-Means Clustering merupakan algoritma akan mengelompokan data kedalam Cluster - Cluster sehingga ketika ada data yang memiliki karkter yang sama maka akan berada pada Cluster yang sama dan data yang memiliki ketidak samaan akan berada di dalam Cluster yang lain, berikuti ini merupakan tahapan perhitungan algoritma Clustering, yaitu: (Sudarsono \& Lestari, 2021)

1. Menentukan banyaknya yang akan di bentuk ada 3 Cluster $(\mathrm{k}=3)$. Untuk penentuan Cluster harus lebih kecil dari pada banyak nya data $(\mathrm{k}<\mathrm{n})$.

2. Menetukan nilai secara manual atau random untuk pusat Cluster awal sebanyak Cluster yang ditentukan.

$V_{i j}=\frac{1}{N_{i}} \sum_{k=0}^{N i} X k j$

Keterangan:

Vij : Centroid rata-rata Cluster ke-1 untuk variabel kej

$\mathrm{Ni}$ : Jumlah anggota Cluster ke-i

$\mathrm{i}, \mathrm{k}$ : Imdeks dari Cluster

$\mathrm{j} \quad$ : Indeks dari Variabel

Xkj: Nilai data ke-k variabel ke-j untuk Cluster tersebut

3. Untuk menghitung jarak data dengan centroid menggunakan rumus Euclidiean Distance.

$$
D e=\sqrt{\left(x_{i}-s_{i}\right)^{2}+\left(y_{i}-t_{i}\right)^{2}} .
$$

Keterangan:

De : Euclidien Distance

i : Banyaknya objek

$(\mathrm{x}, \mathrm{y})$ : Koordinat objek

$(\mathrm{s}, \mathrm{t})$ : Koordinat centroid

4. Mengecek setiap kedekatan data dengan jarak terkecil.

5. Centroid baru akan dihitung dengan melakukan perhitungan nilai rata-rata data pada setiap Cluster.

6. Melakukan perulangan jika perhitungan iterasi yang baru berbeda dengan iterasi sebelumnya, maka proses akan di lanjutkan ke langkah perulangan selanjutnya. Namun jika iterasi yang baru di hitung memiliki hasil yang sama dengan iterasi sebelumnya, maka proses Clustering selesai. Maka nilai pusat Cluster pada iterasi terakhir akan di gunakan sebagai parameter yang dimana untuk menentukan kasifikasi data

Berikut adalah tampilan hasil yang digunakan dengan menerapkan algoritma $K$ Means Clustering dengan menggunakan pengujian aplikasi PHP:

a) Tampilan Awal Pada Aplikasi

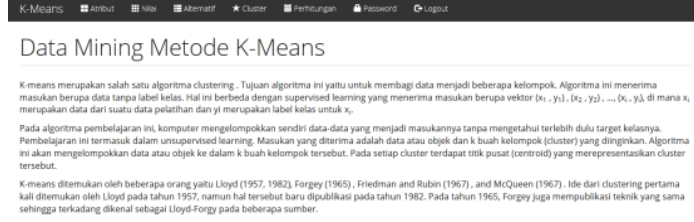

Gambar 2. Tampilan Awal

Tampilan awal berisi tentang penjelasan dari Data Mining Metode K-Means. 
IN F ORM T I K A

Jurnal Informatika, Manajemen dan Komputer, Vol. 13, No. 2, Desember 2021

eISSN : 2580-3042

pISSN : 1979-0694

b) Tampilan Atribut

Atribut

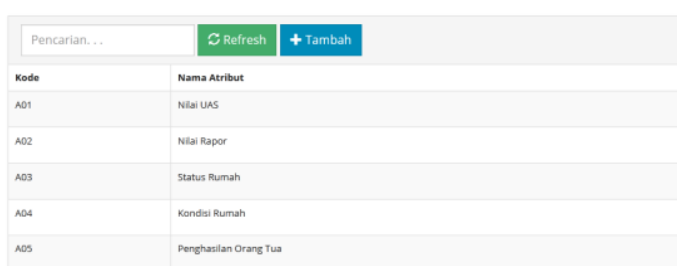

Gambar 3. Tampilan Atribut

Tampilan atribut menjelaskan atribut yang diguanakan untuk perhitungan algoritma $K$ Means Clustering beiri kode dan nama atribut. Kode atribut terdiri dari A01, A02, A03,A04,A05dan nama atributnya terdiri dari Nilai UAS, Nilai Rapor, Status Rumah, Kondisi Rumah, Penghadilan Orang Tua.

c) Tampilan Niali Atribut

Nilai Atribut

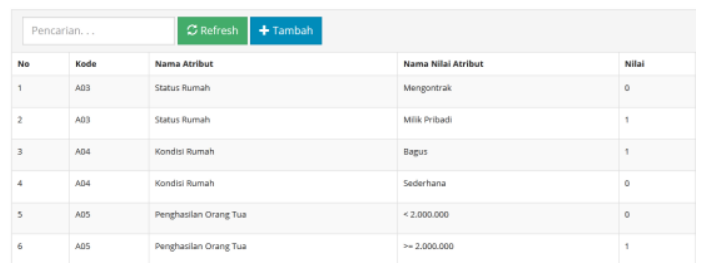

Gambar 4. Tampilan Nilai Atribut

Tampilan nilai atribut berisi tentang nilai dari masing-masing dari atribut. Nilai yang diberikan untuk nilai atribut adalah 0 dan 1 .

\section{d) Tampilan Alternatif}

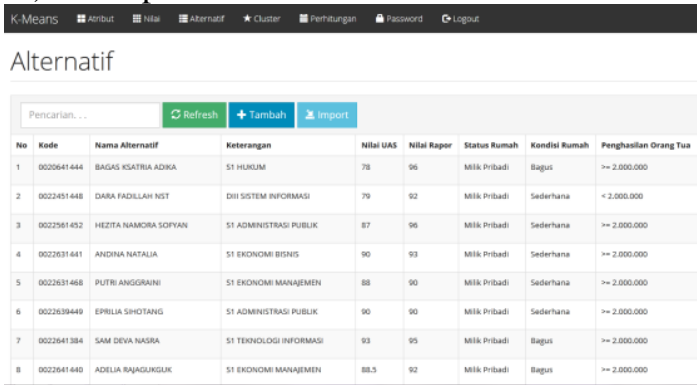

\section{Gambar 5. Tampilan Alternatif}

Tampilan ini berisi data calon mahasiswa penerima beasiswa yayasan yang akan diolah dan dikelompokkan.

e) Tampilan Perhitungan

Dalam tampilan perhitungan ada beberapa tampilan yang dijalankan sekaligus, diantaranya:

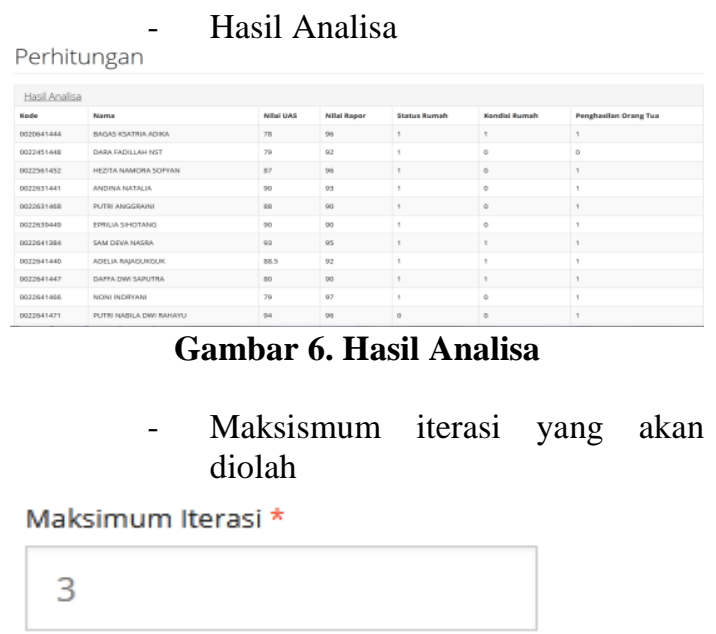

\section{JProses}

\section{Gambar 7. Iterasi}

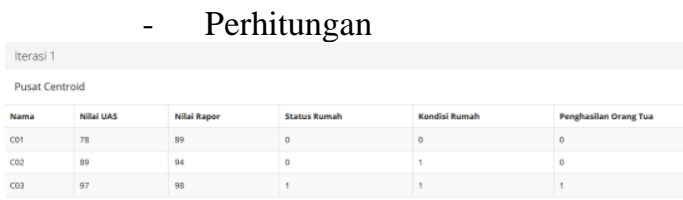

Gambar 8 . Hasil Iterasi 1

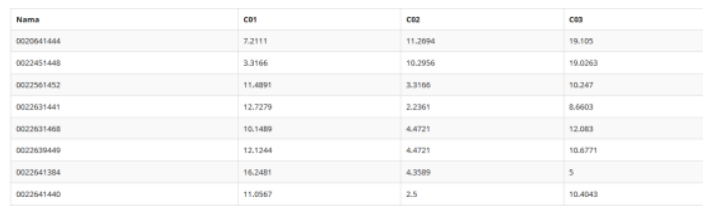

Gambar 9. Jarak Terhadap Pusat Centroid

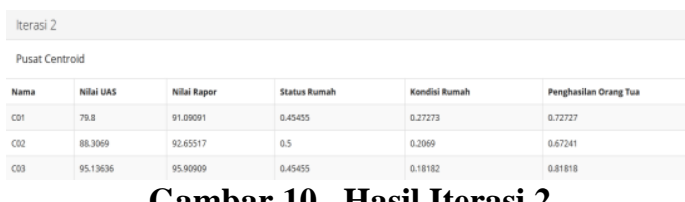

Gambar 10 . Hasil Iterasi 2

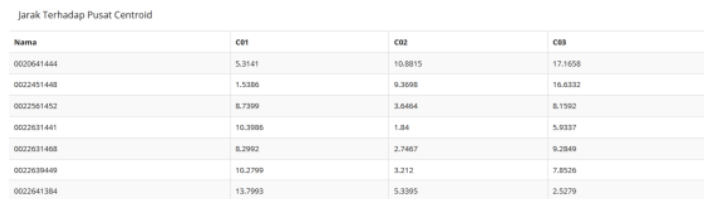

Gambar 11. Jarak Terhadap Pusat Centroid Baru

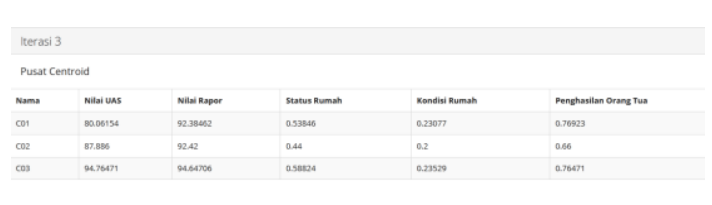

Gambar 12 . Hasil Iterasi 2 
IN F ORM A I I A

Jurnal Informatika, Manajemen dan Komputer, Vol. 13, No. 2, Desember 2021

elSSN : 2580-3042

pISSN : 1979-0694

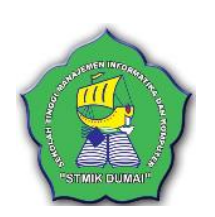

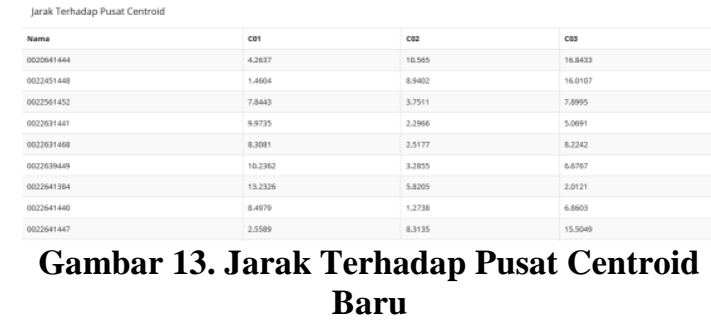

Karena iterasi (3) sudah mencapai maksimum iterasi, maka iterasi dihentikan.

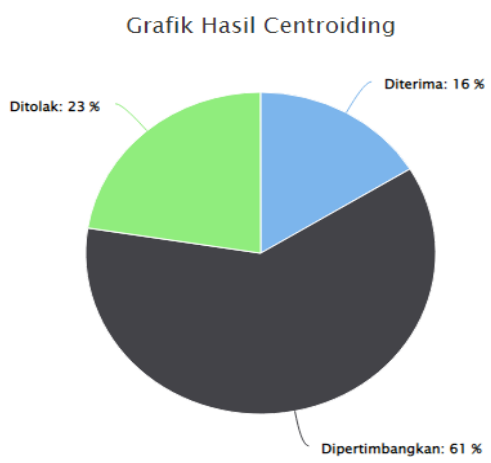

Gambar 14. Grafik Hasil Centroid

Berdasarkan hasil perhitungan yang telah dilakukan, maka didapatkan hasil yang diolah menjadi garfik. Adapun hasil Grafik centroiding adalah 16\% Diterima, 61\%, Dipertimbangkan dan 23\% Ditolak. Dengan hasil diatas menunjukkan bahwa untuk penerima beasiswa banyak calon mahasiswa yang dipertimbangkan.

\section{KESIMPULAN}

Dari hasil pengolahan yang sudah dilakukan maka mendapatkan hasil bahwa banyak calon mahasiswa yang dipertimbangkan untuk penerima beasiswa yayasan, dengan adanya aplikasi ini membuat pekerjaan pihak panitia menjadi lebih ringan hanya dengan memasukkan data calon penerima kedalam apliaksi sesuai dengan kriteria-kriteria yang sudah ditentukan.

\section{REFERENSI}

Ginting, B., \& Riandari, F. (2020). Implementasi Metode K-Means Clustering Dalam Pengelompokan Bibit Tanaman Kopi Arabika. Journal of Innovation Information Technology and Application (JINITA), 2(02),

146-151. https://doi.org/10.35970/jinita.v2i02.394
Hasan, S., \& Muhammad, N. (2020). Sistem Informasi Pembayaran Biaya Studi Berbasis Web Pada Politeknik Sains Dan Teknologi Wiratama Maluku Utara. IJIS Indonesian Journal On Information System, $5(1)$, 44-55. https://doi.org/10.36549/ijis.v5i1.66

Manihuruk, N. A., Zarlis, M., Irawan, E., \& Tambunan, H. S. (2020). Penerapan Data Mining Dalam Mengelompokkan Calon Penerima Beasiswa Dengan Menggunakan Algoritma K-Means. KOMIK (Konferensi Nasional Teknologi Informasi Dan Komputer), 4(1), 29-34. https://doi.org/10.30865/komik.v4i1.2575

Putri, sanni ucha, Irawan, E., \& Rizky, F. (2021). Implementasi Data Mining Untuk Prediksi Penyakit Diabetes. KESATRIA( Jurnal Penerapan Sistem Informasi Dan Manajemen, 2(1), 39-46.

Putri, E. E. (2020). Analisis tingkat kejahatan jalanan menggunakan metode fp-growth (studi kasus di polresta padang). Syntax: Journal of Software Engineering, Computer Science and Information Technology, 1(1), 10-15.

Rahayu, A. E., Hikmah, K., Yustia, N., \& Fauzan, A. C. (2019). Penerapan K-Means Clustering Untuk Penentuan Klasterisasi Beasiswa Bidikmisi Mahasiswa. ILKOMNIKA: Journal of Computer Science and Applied Informatics, 1(2), 8286.

https://doi.org/10.28926/ilkomnika.v1i2.23

Rahmah, S. A. (2020). KLASTERISASI POLA PENJUALAN PESTISIDA MENGGUNAKAN METODE K-MEANS CLUSTERING ( STUDI KASUS DI TOKO JUANDA TANI KECAMATAN HUTABAYU RAJA ). 1(1), 1-5. http://jurnal.dharmawangsa.ac.id/index.php /djtechno/article/view/964

Salam, A., Adiatma, D., \& Zeniarja, J. (2020). Implementasi Algoritma K-Means Dalam Pengklasteran untuk Rekomendasi Penerima Beasiswa PPA di UDINUS. JOINS (Journal of Information System), 5(1), 62-68. https://doi.org/10.33633/joins.v5i1.3350 
IN F ORM A I K A

Jurnal Informatika, Manajemen dan Komputer, Vol. 13, No. 2, Desember 2021

eISSN : 2580-3042

pISSN : 1979-0694

Sudarsono, B. G., \& Lestari, S. P. (2021).

Clustering Penerima Beasiswa Yayasan

Untuk Mahasiswa. 5, 258-263.

https://doi.org/10.30865/mib.v5i1.2670

Teknologi, J., Jtsi, I., Provinsi, D. I., Dengan, L., \& Means, A. K.-. (2021). ANALISIS DATA MINING UNTUK CLUSTERING KASUS COVID-19. 2(2), 100-108. 